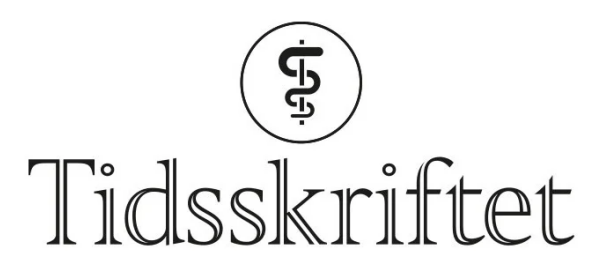

DEN NORSKE LEGEFORENING

\title{
Alt som kan sies på engelsk, kan sies på norsk
}

\author{
FRA REDAKTØREN
}

\section{PETTER GJERSVIK}

petter.gjersvik@medisin.uio.no

Petter Gjersvik er medisinsk redaktør i Tidsskriftet og professor ved Institutt for klinisk medisin, Universitetet i Oslo.

\section{Leger må skrive og snakke slik at de blir forstått. Å finne gode oversettelser av engelske faguttrykk er lettere enn det mange tror.}

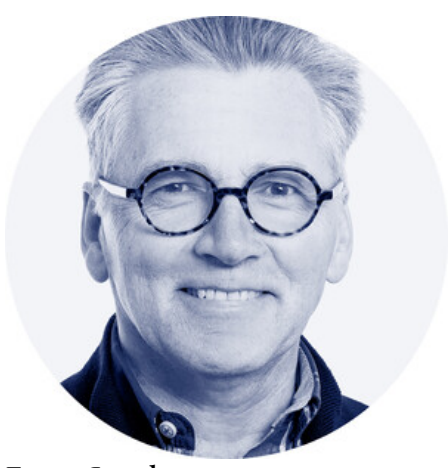

Foto: Sturlason

Vi bruker språk for å tenke og for å registrere observasjoner, tanker og vurderinger. Vi bruker språk for å bli forstått og for å formidle et budskap. Å beherske språk er derfor like viktig for en lege og forsker som oppdatert kunnskap og praktiske ferdigheter (1) .

Engelsk er i dag det dominerende internasjonale språket i medisin. De fleste vitenskapelige tidsskriftene publiseres på engelsk, og alle større internasjonale kongresser, også nordiske, gjennomføres på engelsk. Også norsk allmennspråk er under press fra engelsk. Det er derfor ikke til å undres over at nye engelske faguttrykk og formuleringer lett får innpass i Norge. Mange fagfolk vil foretrekke - og noen insistere på - å bruke engelske faguttrykk også når de skriver og snakker på norsk. Det er enkelt å ta dem i bruk.

Noen vil mene at dette er tegn på språklig latskap, men like viktig er det nok at de fleste leger ikke har trening i hvordan man skal lage gode oversettelser. Bruk av engelske faguttrykk som er vanskelige å forstå for utenforstående, kan dermed stå i veien for god 
presentasjon og formidling av forskning. Fagspråket blir et stammespråk, tilgjengelig kun for de innvidde.

«Vi må bruke engelskspråklige faguttrykk fordi alle i fagmiljøene bruker dem» er en vanlig begrunnelse. Dette kan være en rimelig forklaring når målgruppen kun er kolleger i eget fagmiljø. Men ikke når man henvender seg til fagfolk utenfor sitt eget fagmiljø, inkludert leger som ikke kjenner temaet like godt, og absolutt ikke når målgruppen er pasienter, pårørende eller allmennhet. Og har man først lagt seg til bruk av et engelsk faguttrykk, er det ofte vanskelig å slå over til norsk i andre sammenhenger.

Det kan også være en annen og mer psykologisk forklaring for at noen tviholder på engelske faguttrykk: et ønske om å være eksklusiv. Får fagpersonen en opplevelse av å tilhøre en liten gruppe med forbindelser til den store verden? At man er oppdatert og følger med på det siste nye? At dette er så vanskelig at det bare er vi - vi med innsikt og erfaring - som forstår hvor komplisert dette egentlig er? Det er nok også slik at nordmenn flest ikke har samme språklige bevissthet og stolthet over sitt språk som bl.a. franskmenn og islendinger.

\section{"Sjansen for at et norsk avløserord blir tatt $i$ bruk, øker hvis man er tidlig ute og sentrale fagpersoner er involvert»}

En mye brukt begrunnelse for å bruke engelske faguttrykk er at «uttrykket ikke lar seg oversette til norsk», og at forslag til oversettelser er for upresise eller lite dekkende. Noen vil mene at forslag til norske oversettelser klinger merkelig, fremmed eller uheldig i norske $\emptyset$ rer. De glemmer da at engelske uttrykk ofte kan ha de samme konnotasjoner blant engelskspråklige personer som det norske avløserordet kan ha blant nordmenn (므). Forslag kan bli møtt med forundring, uvilje eller latter i aktuelle fagmiljøer, men det finnes også eksempler på at oversettelser som først møter motstand, etter hvert likevel vinner innpass.

Selvsagt kan det mange ganger være vanskelig å finne norske avløserord for engelske faguttrykk. Jeg vil likevel hevde at det er mye lettere enn det mange tror. Ved bruk av nettbaserte ordbøker og oversetterprogram vil man finne aktuelle ord som kan danne grunnlag for norske avløserord. Vaktpostlymfeknute (for sentinel node), ikke-underlegenhet (for non-inferiority) og røvertidsskrift (for predatory journals) er gode eksempler på dette (3-6). Sjansen for at et norsk avløserord blir tatt i bruk, øker hvis man er tidlig ute og sentrale fagpersoner er involvert. Likevel kan det å etablere et norsk faguttrykk til erstatning for et engelsk ta lang tid og kreve utholdenhet. En stund vil kanskje det norske og det engelske uttrykket leve side om side. Hvis man er sent ute, kan løpet være kjørt. Og et avløserord vil bortfalle hvis det viser seg å ikke ha livets rett.

Godt språk og bruk av norske faguttrykk er viktig i de fleste fag, men særlig i medisin og andre helsefag, fordi leger og annet helsepersonell skal kommunisere om liv og helse direkte med pasienter og pårørende. Man kan gjerne bruke betegnelsen helsespråk, som Erlend Hem og Magne Nylenna skriver om i Språkspalten (7.). På initiativ fra dem og Gruppe for norsk medisinsk fagspråk, der Tidsskriftet er representert, gjennomføres 21.5.2021 et tverrfaglig nettseminar om helsespråk (7.). Tidsskriftets lesere og andre språkinteresserte inviteres herved til å kople seg på med sin PC eller smarttelefon. Arrangørenes målsetning er bl.a. å styrke helsepersonells språkbevissthet og deres erkjennelse av hvor viktig det er å bruke et godt og forståelig språk.

En lengre utgave av denne artikkelen vil bli publisert i boken Helsespråk (6). Overskriften er fra et sitat av Raida Ødegaard, mangeårig manuskriptredaktør i Tidsskriftet (8).

LITTERATUR

1. Gjersvik P. Språket er en del av faget. Tidsskr Nor Legeforen 2012; 132: 613. [PubMed][CrossRef] 
2. Wyller TB, Hem E. De skrøpelige. Tidsskrift for omsorgsforskning 2020; 6: 1-3. [CrossRef]

3. Schlichting E, Babovic A, Kåresen R. Vaktpostlymfeknute. Tidsskr Nor Laegeforen 1999; 119: 2009. [PubMed]

4. Gjersvik P, Hem E, Jacobsen GW et al. Hva bør non-inferiority-studier kalles på norsk? Tidsskr Nor Legeforen 2014; 134: 852-3. [PubMed][CrossRef]

5. Hem E. Se opp for røvertidsskrifter. Tidsskr Nor Legeforen 2014; 134: 1273. [PubMed][CrossRef]

6. Gjersvik P. Norske faguttrykk fremfor engelske: Hvorfor så vanskelig, hvorfor så lett? I: Hem E, Nylenna M, red. Helsespråk. Michael 2021; 18: Supplement 26.

7. Hem E, Nylenna M. Hva er helsespråk? Tidsskr Nor Legeforen 2021; 141. doi:10.4045/tidsskr.21.0224. [CrossRef]

8. Feiring E. Språkdoktoren. Tidsskr Nor Legeforen 2013; 133: 1346-7. [CrossRef]

Publisert: 21. april 2021. Tidsskr Nor Legeforen. DOI:10.4045/tidsskr.21.026o

(c) Tidsskrift for Den norske legeforening 2023. Lastet ned fra tidsskriftet.no 26. april 2023. 